\title{
Influence of obesity and insulin sensitivity on phospholipid transfer protein activity
}

\author{
S. Kaser ${ }^{1}$, A.Sandhofer ${ }^{1}$, B. Föger ${ }^{1}$, C. F. Ebenbichler ${ }^{1}$, B. Igelseder ${ }^{3}$, L. Malaimare ${ }^{2}$, B.Paulweber ${ }^{2}$, J. R.Patsch ${ }^{1}$ \\ ${ }^{1}$ Department of Internal Medicine, University of Innsbruck, Innsbruck, Austria \\ ${ }^{2}$ First Department of Internal Medicine, General Hospital Salzburg, Salzburg, Austria \\ ${ }^{3}$ Department of Neurology, Christian Doppler Klinik, Salzburg, Austria
}

\section{Abstract}

Aims/hypothesis. Phospholipid transfer protein plays a key role in lipoprotein metabolism by catalysing the transfer of phospholipids from triglyceride-rich lipoproteins to high-density lipoproteins and, also, within the high-density lipoprotein family, from particle to particle. This transfer results in a change of HDL particle size and the generation of pre- $\beta$-highdensity lipoproteins which function as initial lipid acceptors in the process of reverse cholesterol transport. Because adipose tissue is a source of phospholipid transfer protein we investigated the influence of obesity and insulin sensitivity on phospholipid transfer protein activity.

Methods. Using an exogenous substrate assay phospholipid transfer protein activity was measured in plasma specimens of 190 normolipidaemic, non-diabetic subjects with BMI ranging from 19 to $43 \mathrm{~kg} / \mathrm{m}^{2}$. Insulin sensitivity was measured by the short insulin tolerance test.

Results. Phospholipid transfer protein activity was associated with BMI $(r=0.46, p<0.01)$, body fat mass $(r=0.39, p<0.01)$, subcutaneous fat area $(r=0.32$, $p<0.01)$ and plasma leptin concentration $(r=0.24$, $p<0.01$ ) but not with insulin sensitivity expressed as the $\mathrm{k}_{\mathrm{s}}$ of the insulin tolerance test (kITT value) $(r=-0.14, p=0.40)$. Accordingly, phospholipid transfer protein activity was higher in obese than in nonobese subjects. As determined by linear regression analysis, BMI was the sole predictor of phospholipid transfer protein activity in plasma explaining $22.2 \%$ of the activity $(p<0.01)$.

Conclusions/interpretations. This data suggests that increased phospholipid transfer protein activity in obese subjects is a consequence of obesity itself without the contribution of insulin resistance and can be explained by increased synthesis of phospholipid transfer protein from the enlarged mass of adipose tissue. [Diabetologia (2001) 44: 1111-1117]

Keywords Phospholipid transfer protein, obesity, insulin sensitivity, adipose tissue, body mass index.
Phospholipid transfer protein (PLTP) is a key enzyme for the metabolism of lipoproteins, particularly that of high-density lipoproteins (HDL), and thus

Received: 20 April 2001 and in revised form: 21 May 2001

Corresponding author: Josef R.Patsch, MD, Department of Medicine, University of Innsbruck, Anichstraße 35, A-6020 Innsbruck, Austria, E-mail: josef.patsch@uklibk.ac.at Abbreviations: PLTP, phospholipid transfer protein; TGRL, triglyceride-rich lipoproteins, apo, apolipoprotein; PC, phosphatidylcholine; CETP, cholesteryl ester transfer protein; kITT $\mathrm{k}_{\mathrm{s}}$, of the insulin tolerance test; ITT, insulin tolerance test for reverse cholesterol transport from peripheral tissues to the liver. PLTP is an $81-\mathrm{kDa}$, hydrophobic protein, expressed mainly in human ovary, thymus, placenta, lung and adipose tissue [1-4]. PLTP transfers phospholipids from triglyceride-rich lipoproteins (TGRL) to HDL and, by transferring surface phospholipids between HDL particles, facilitates the conversion of HDL into smaller and larger particle species [5-8]. Incorporation of phospholipids into the HDL particle surface leads to a displacement of apolipoprotein (apo) A-I and the generation of pre- $\beta$ HDL known to function as initial acceptors of none- 
sterified cholesterol and phospholipids from cell surfaces $[9,10]$.

Both overexpression of PLTP [11-13] and targeted disruption of the PLTP-gene in mice cause dramatic reductions of HDL-cholesterol (HDL-C) in plasma [14]. Different mechanisms are thought to be involved in these apparently conflicting observations: the reduction of HDL-C observed in PLTP ${ }^{-/-}$mice could be due to a reduced transfer of surface components from TGRL into HDL, altering the stability of HDL particles [14]. The reduction of HDL-C concentrations with overexpression of PLTP [11] has been explained by an accelerated HDL catabolism.

Obesity is increasingly prevalent in the Western world and is a risk factor for many illnesses, particularly for atherosclerosis and cancer and also for overall mortality [15-18]. Recently, upgrading obesity from a contributing risk factor to a major risk factor for coronary heart disease has been discussed [19]. Obesity is also associated with Type II (non-insulindependent) diabetes mellitus, hypertension and dyslipidaemia characterized by hypertriglyceridaemia and low HDL-C concentrations [20, 21]. Data on PLTP activity in obesity are conflicting [22-24]: in two studies PLTP activity was found increased in obese patients when compared to healthy non-obese subjects [22, 24], while in another no difference was found between obese and lean individuals [23]. Euglycaemic clamp studies showed a more pronounced suppressive effect of insulin on PLTP activity in healthy subjects than Type II diabetic patients which suggests an association between PLTP activity and insulin resistance [22, 25].

Therefore, we tested PLTP, one of the key enzymes for HDL metabolism, individually in obesity and in insulin resistance in order to investigate some aspects of lipoprotein metabolism in this clinical setting.

\section{Subjects and methods}

Subjects. Altogether 190 subjects, 77 men between 40 and 60 years and 113 women between 50 and 70 years with stable body weight and consuming a typical Western diet participated in the study. All subjects were normolipidaemic with LDL-C below $3.9 \mathrm{mmol} / 1$, TG below $1.71 \mathrm{mmol} / 1$, HDL-C below $0.9 \mathrm{mmol} / \mathrm{l}$ in men and below $1.04 \mathrm{mmol} / \mathrm{l}$ in women and had fasting glucose concentrations below $6.11 \mathrm{mmol} / \mathrm{l}$. Patients with clinical evidence of coronary heart disease, other heart diseases, vitia cordis, cerebrovascular disorders, peripheral vascular disorders, drug abuse, pregnancy, renal or hepatic diseases, malignancies, thyroid dysfunction and patients taking drugs that could affect lipid metabolism or glucose homeostasis, respectively, were excluded from the study. The study protocol was approved by the local ethics committee. Informed consent was obtained from each participant.
Study design. Subjects were divided into quartiles according to their BMI (first quartile (Q1): BMI $<23.4 \mathrm{~kg} / \mathrm{m}^{2}$, second quartile (Q2): BMI 23.4-25.4 $\mathrm{kg} / \mathrm{m}^{2}$, third quartile (Q3): BMI $25.4-28 \mathrm{~kg} / \mathrm{m}^{2}$, fourth quartile (Q4) BMI $>28 \mathrm{~kg} / \mathrm{m}^{2}$ ). With respect to insulin sensitivity as measured by the short insulin tolerance test (kITT values), subjects of the fourth quartile (Q4) were subdivided into tertiles [first tertile (T1): kITT $>4.0 \%$ / min, second tertile (T2) kITT: $2.8-4.0 \% / \mathrm{min}$, third tertile (T3) $<2.8 \% / \mathrm{min}]$.

Insulin sensitivity. We used the short insulin tolerance test (ITT) [26]. Blood glucose was measured before and $15 \mathrm{~min}$ after an intravenous bolus of short-acting insulin $(0.1 \mathrm{U} / \mathrm{kg}$ body weight). Insulin sensitivity was expressed as $\mathrm{k}_{\mathrm{s}}$ value (kITT) (\% decrease in plasma glucose concentration/minute). Insulin sensitivity was also estimated by the homeostasis model assessment (HOMA) index [27].

Laboratory measurements. Venous blood was drawn after an overnight fast and plasma was obtained by centrifugation at $3000 \mathrm{rpm}$ for $10 \mathrm{~min}$ at $4{ }^{\circ} \mathrm{C}$ immediately after blood collection. Plasma samples were either used immediately for analysis or were stored frozen at $-80^{\circ} \mathrm{C}$. Cholesterol, HDL-C, TG and venous plasma glucose concentrations were measured using commercially available enzymatic kits (Roche Diagnostics, Mannheim, Germany), apolipoprotein A-I and B plasma concentrations were measured using turbidimetric assays (Roche Diagnostics). Fasting plasma insulin concentrations were measured by a microparticle enzyme immunoassay on an IMx analyser (IMx system No.2A10-20, Abbott Diagnostics, Abbott Park, Ill., USA). $\mathrm{HbA}_{1 \mathrm{c}}$ values were determined by a commercially available turbidimetric assay (Roche Diagnostics). Plasma leptin concentrations were measured by an enzyme-linked immunosorbent assay according to the manufacturer's instructions (R\&D Systems, Wiesbaden, Germany).

Determination of body fat distribution. Areas of abdominal subcutaneous and visceral fat were assessed by computed tomography (CT) scan (Picker CT MXTWIN, Picker International, Cleveland, Ohio, USA) using a single cross-section at position L4/5. Body composition was determined by body impedance analysis (B. I. A. 2000-M, Data Input, Frankfurt, Germany) according to standard protocols.

PLTP activity assay. The ability of plasma to transfer ${ }^{3} \mathrm{H}$-dipalmitoyl-phosphatidylcholine ( $\left.{ }^{3} \mathrm{H}-\mathrm{PC}\right)$ (NEN Life Science Products, Boston, Mass., USA) from phosphatidylcholine (PC) vesicles to $\mathrm{HDL}_{3}$ was measured as described previously $[11,25,28,29]$. In brief, the reaction mixture containing $10 \mu \mathrm{mol}$ of L- $\alpha$-PC (Sigma, St. Louis, Mo., USA), $2 \mu \mathrm{Ci}{ }^{3} \mathrm{H}-$ $\mathrm{PC}$ and $0.1 \mu \mathrm{mol}$ of butylated hydroxytoluene (Sigma) was dried down under $\mathrm{N}_{2}$ and resuspended in $1 \mathrm{ml}$ of $150 \mathrm{mmol} / \mathrm{l}$ $\mathrm{NaCl}, 10 \mathrm{mmol} / \mathrm{l}$ TRIS-HCl, 1 mmol/l EDTA (pH 7.4). After sonication of the mixture, lipid aggregates and titanium debris were removed by centrifugation. Four $\mu$ litres of plasma were incubated with ${ }^{3} \mathrm{H}-\mathrm{PC}$ vesicles and $\mathrm{HDL}_{3}$ in a final volume of $400 \mu \mathrm{l}$ of $150 \mathrm{mmol} / \mathrm{l} \mathrm{NaCl}, 10 \mathrm{mmol} / \mathrm{l}$ TRIS-HCl (pH 7.4). $\mathrm{HDL}_{3}$ were obtained by zonal ultracentrifugation [30]. After an incubation period of $1 \mathrm{~h}$ at $37^{\circ} \mathrm{C}$ in a shaking waterbath vesicles were separated from $\mathrm{HDL}_{3}$ by the addition of $300 \mu \mathrm{l}$ of a $500 \mathrm{mmol} / \mathrm{l} \mathrm{NaCl}, 215 \mathrm{mmol} / \mathrm{l} \mathrm{MnCl}_{2}$ and $445 \mathrm{U} / \mathrm{ml}$ heparin and subsequent centrifugation for $10 \mathrm{~min}$ at $11000 \mathrm{~g}$. Radioactivity in the supernatant was counted in a LS 6500 Scintillation Counter (Beckman, Palo Alto, Calif., USA). 
Table 1. Clinical characteristics of 190 study subjects dependent on their BMI

\begin{tabular}{|c|c|c|c|c|}
\hline & \multicolumn{4}{|c|}{ Quartiles of BMI } \\
\hline & $\begin{array}{l}\text { Q1 }(n=48) \\
<23.4 \mathrm{~kg} / \mathrm{m}^{2}\end{array}$ & $\begin{array}{l}\mathrm{Q} 2(n=48) \\
23.4-25.4 \mathrm{~kg} / \mathrm{m}^{2}\end{array}$ & $\begin{array}{l}\mathrm{Q} 3(n=46) \\
25.4-28 \mathrm{~kg} / \mathrm{m}^{2}\end{array}$ & $\begin{array}{l}\text { Q4 }(n=48) \\
>28 \mathrm{~kg} / \mathrm{m}^{2}\end{array}$ \\
\hline Age (years) & $55 \pm 6$ & $54 \pm 6$ & $52 \pm 7$ & $56 \pm 6$ \\
\hline Sex (male/female) & $14 \mathrm{~m}, 34 \mathrm{f}$ & $22 \mathrm{~m}, 26 \mathrm{f}$ & $23 \mathrm{~m}, 24 \mathrm{f}$ & $18 \mathrm{~m}, 29 \mathrm{f}$ \\
\hline $\operatorname{BMI}\left(\mathrm{kg} / \mathrm{m}^{2}\right)$ & $22.0 \pm 0.9$ & $24.2 \pm 0.6$ & $26.6 \pm 0.8$ & $31.8 \pm 3.1$ \\
\hline Waist-to-hip ratio & $0.83 \pm 0.08^{b, c, d}$ & $0.85 \pm 0.07^{\mathrm{a}, \mathrm{c}, \mathrm{d}}$ & $0.88 \pm 0.06^{\mathrm{a}, \mathrm{b}}$ & $0.91 \pm 0.08^{\mathrm{a}, \mathrm{b}}$ \\
\hline Subcutaneous fat area $\left(\mathrm{cm}^{2}\right)$ & $166 \pm 57^{\mathrm{c}, \mathrm{d}}$ & $177 \pm 60^{\mathrm{c}, \mathrm{d}}$ & $238 \pm 80^{\mathrm{a}, \mathrm{b}, \mathrm{d}}$ & $343 \pm 110^{\mathrm{a}, \mathrm{b}, \mathrm{c}}$ \\
\hline
\end{tabular}

Values are means \pm SD

${ }^{\mathrm{a}} p<0.05$ vs Q1; ${ }^{\mathrm{b}} p<0.05$ vs Q2; ${ }^{\mathrm{c}} p<0.05$ vs Q3; ${ }^{\mathrm{d}} p<0.05$ vs Q4

Table 2. Lipoprotein profile and parameters of glucose homeostasis of 190 subjects dependent on their BMI

\begin{tabular}{|c|c|c|c|c|}
\hline & \multicolumn{4}{|c|}{ Quartiles of body mass index } \\
\hline & $\begin{array}{l}\text { Q1 }(n=48) \\
<23.4 \mathrm{~kg} / \mathrm{m}^{2}\end{array}$ & $\begin{array}{l}\mathrm{Q} 2(n=48) \\
23.4-25.4 \mathrm{~kg} / \mathrm{m}^{2}\end{array}$ & $\begin{array}{l}\mathrm{Q} 3(n=46) \\
25.4-28 \mathrm{~kg} / \mathrm{m}^{2}\end{array}$ & $\begin{array}{l}\mathrm{Q} 4(n=48) \\
>28 \mathrm{~kg} / \mathrm{m}^{2}\end{array}$ \\
\hline $\mathrm{TG}(\mathrm{mmol} / \mathrm{l})$ & $0.93 \pm 0.33$ & $0.88 \pm 0.35$ & $1.04 \pm 0.30$ & $1.12 \pm 0.32$ \\
\hline LDL-C (mmol/l) & $3.16 \pm 0.62$ & $3.16 \pm 0.44$ & $3.37 \pm 0.41$ & $3.21 \pm 0.49$ \\
\hline HDL-C (mmol/l) & $1.84 \pm 0.39$ & $1.79 \pm 0.36$ & $1.68 \pm 0.34$ & $1.58 \pm 0.44$ \\
\hline Apo A-I $(g / l)$ & $1.74 \pm 0.27^{\mathrm{d}}$ & $1.71 \pm 0.23^{\mathrm{d}}$ & $1.65 \pm 0.25$ & $1.60 \pm 0.31^{\mathrm{a}, \mathrm{b}}$ \\
\hline Fasting insulin $(\mu \mathrm{U} / \mathrm{ml})$ & $5.1 \pm 2.3^{\mathrm{d}}$ & $5.1 \pm 1.2^{\mathrm{d}}$ & $5.8 \pm 3.2^{\mathrm{d}}$ & $11.5 \pm 7.4^{\mathrm{a}, \mathrm{b}, \mathrm{c}}$ \\
\hline $\mathrm{HbA}_{1 \mathrm{c}}(\%)$ & $5.5 \pm 0.3$ & $5.4 \pm 0.3^{\mathrm{d}}$ & $5.5 \pm 0.2^{\mathrm{d}}$ & $5.6 \pm 0.4^{\mathrm{b}, \mathrm{c}}$ \\
\hline kITT value (\%/min) & $4.73 \pm 1.10^{\mathrm{d}}$ & $4.65 \pm 1.3^{\mathrm{d}}$ & $4.62 \pm 1.11^{\mathrm{d}}$ & $3.82 \pm 1.48^{\mathrm{a}, \mathrm{b}, \mathrm{c}}$ \\
\hline HOMA index & $1,16 \pm 0.51^{\mathrm{d}}$ & $1,14 \pm 0,54^{\mathrm{d}}$ & $1,31 \pm 0,80^{\mathrm{d}}$ & $2,85 \pm 2,29^{a, b, c}$ \\
\hline Leptin $(\mathrm{ng} / \mathrm{ml})$ & $7.1 \pm 4.9^{\mathrm{c} d}$ & $7.3 \pm 6.0^{\mathrm{d}}$ & $11.0 \pm 8.5^{\mathrm{a}, \mathrm{d}}$ & $18.6 \pm 15.5^{\mathrm{a}, \mathrm{b}, \mathrm{c}}$ \\
\hline PLTP activity $\left(\mu \mathrm{mol} \cdot \mathrm{ml}^{-1} \cdot \mathrm{h}^{-1}\right)$ & $11.89 \pm 2.31^{\mathrm{d}}$ & $11.86 \pm 2.81^{\mathrm{d}}$ & $12.81 \pm 1.78^{\mathrm{d}}$ & $15.10 \pm 3.03^{\mathrm{a}, \mathrm{b}, \mathrm{c}}$ \\
\hline
\end{tabular}

Values are means $\pm \mathrm{SD}$

${ }^{\mathrm{a}} p<0.05$ vs Q1; ${ }^{p} p<0.05$ vs Q2; ${ }^{\mathrm{c}} p<0.05$ vs Q3; ${ }^{\mathrm{d}} p<0.05$ vs Q4

Statistical analysis. Descriptive data are expressed as means \pm SD. The significance of differences in means between more than two groups was tested by ANOVA with the Bonferroni correction. Correlation coefficients were calculated with Pearson's method. Partial correlation of parameters was used to correct for other parameters. Statistical significance was inferred at a two-tailed $p$ value of less than 0.05 . A stepwise regression analysis was done by entering the independent variable with the highest partial correlation coefficient at each step, until no variable remained with an $\mathrm{F}$ value of 4 or more. Statistical analyses were done using the statistical software package SPSS for Windows (Version 8.0) (SPSS, Chicago, Ill., USA).

\section{Results}

Study population. The study cohort comprised 190 subjects who were subdivided into quartiles according to their BMI (Q1: $\mathrm{BMI}<23.4 \mathrm{~kg} / \mathrm{m}^{2}, \mathrm{Q} 2$ : $\mathrm{BMI}$ : 23.4-25.4 kg/m², Q3: BMI: $25.4-28 \mathrm{~kg} / \mathrm{m}^{2}$, Q4: BMI $>28 \mathrm{~kg} / \mathrm{m}^{2}$ ). The clinical characteristics of the patients are listed in Table 1 . As shown in Table 2, fasting plasma glucose, fasting plasma insulin concentrations and $\mathrm{HbA}_{1 \mathrm{c}}$ values were highest in Q4, kITT values were lowest in this group. Lipid parameters of the four subgroups are also summarized in Table 2. Total cholesterol, TG, LDL-C and HDL-C concentrations were comparable between the four subgroups.

PLTP activity and BMI. PLTP activities were significantly higher in the group with the highest BMI (Q4) $\left(15.10 \pm 3.03 \mu \mathrm{mol} \cdot \mathrm{ml}^{-1} \cdot \mathrm{h}^{-1}, n=48\right)$ when compared to the groups Q1 $(11.89 \pm 2.31 \mu \mathrm{mol}$. $\left.\mathrm{ml}^{-1} \cdot \mathrm{h}^{-1}, p<0.01, n=48\right), \mathrm{Q} 2(11.86 \pm 2.81 \mu \mathrm{mol}$. $\left.\mathrm{ml}^{-1} \cdot \mathrm{h}^{-1}, \quad p<0.01, \quad n=48\right) \quad$ and Q3 $(12.81 \pm$ $1.78 \mu \mathrm{mol} \cdot \mathrm{ml}^{-1} \cdot \mathrm{h}^{-1}, p<0.01, n=46$ ) (Fig. 1), while differences in PLTP activity between Q1, Q2 or Q3 did not reach statistical significance.

Correlations. PLTP activity correlated positively with BMI $(r=0.46, p<0.01)$, subcutaneous fat area $(r=0.32, p<0.01)$, body fat mass $(r=0.39, p<0.01)$, plasma leptin concentrations $(r=0.24, p<0.01)$ and waist-to-hip ratio $(r=0.16, p=0.03)$, respectively. Positive correlations were also found between PLTP activity and fasting plasma insulin concentration 


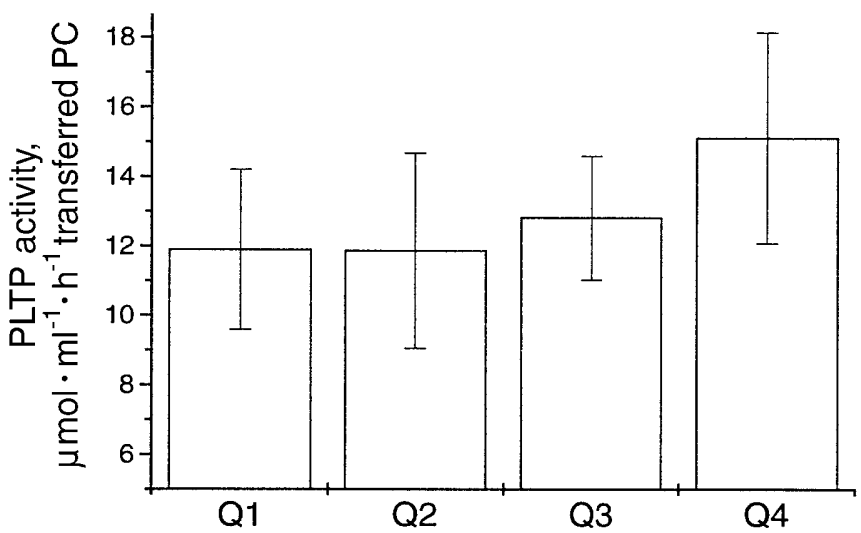

Fig. 1. PLTP activity in patients with different BMI. The study cohort was subdivided into four groups according to BMI (Q1: BMI $<23.4 \mathrm{~kg} / \mathrm{m}^{2}, \mathrm{Q} 2: \mathrm{BMI}<25.4 \mathrm{~kg} / \mathrm{m}^{2}, \mathrm{Q} 3: \mathrm{BMI}<28 \mathrm{~kg} / \mathrm{m}^{2}$, Q4: BMI $>28 \mathrm{~kg} / \mathrm{m}^{2}$ ). PLTP activity was highest in group Q4 $(p<0.01) . \mathrm{Q}$, quartiles of BMI. Means $\pm \mathrm{SD}$

$(r=0.28, p<0.01)$, fasting plasma glucose concentrations $(r=0.18, p=0.01)$ and the HOMA index $(r=0.27, p<0.01)$ but not with insulin sensitivity expressed as kITT value (Fig. 2A).

After correction for kITT values, the positive correlation between PLTP activity and BMI $(r=0.46$, $p<0.01)$ (Fig. 2B), body fat mass $(r=0.36, p<0.01)$, subcutaneous fat area $(r=0.29, p<0.01)$ and leptin concentrations $(r=0.20, p=0.01)$ persisted. When corrected for the HOMA index, PLTP activity was positively correlated with BMI $(r=0.40, p<0.01)$, body fat mass $(r=0.29, p<0.01)$, subcutaneous fat area $(r=0.23, p=0.01)$ and leptin concentrations $(r=0.17, p=0.05)$, respectively. After correction for BMI, waist-to-hip ratio, subcutaneous fat area, visceral fat area, body fat mass and plasma leptin concentrations, respectively, the correlation between PLTP activity and fasting plasma insulin or glucose concentrations and the HOMA index disappeared. As determined by linear regression analysis, BMI was the sole predictor of PLTP activity in plasma $(p<0.01)$ explaining $22.2 \%$ of the activity in this study $(p<0.01)$.

PLTP activity and insulin sensitivity. To test for the influence of insulin sensitivity on PLTP activity in obesity, the subjects of the group with the highest BMI (Q4) were subdivided further into tertiles according to insulin sensitivity expressed as kITT value (T1: kITT $>4 \% / \mathrm{min}, \quad \mathrm{T} 2: \quad \mathrm{kITT}: \quad 2.8-4 \% / \mathrm{min}, \quad \mathrm{T} 3$ : kITT $<2.8 \% / \mathrm{min}$ ) (Table 3 ). The groups did not differ in BMI, waist-to-hip ratio, subcutaneous or visceral fat area or body fat mass, respectively. Fasting plasma insulin concentrations increased statistically significantly from T1 to T3 and kITT value significantly decreased from T1 to T3 (Table 4).

No statistically significant differences in PLTP activities were found between groups T1 (15.70 \pm
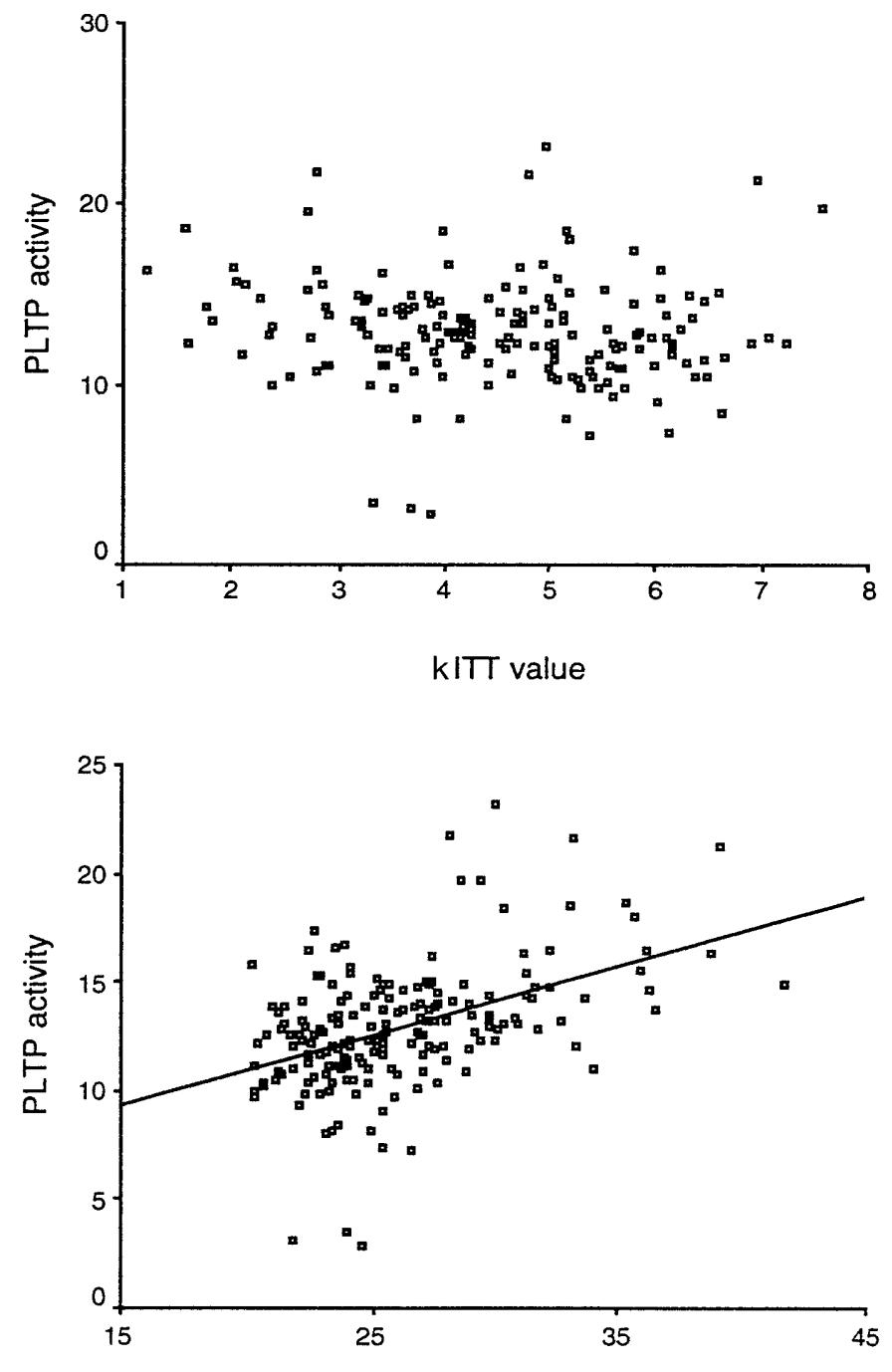

$\mathrm{BMI}$

Fig. 2. Correlation between PLTP activity and kITT or BMI value in all study subjects. Note the lack of correlation between PLTP activity and kITT value after correction for BMI, waist-to-hip ratio, body fat mass, subcutaneous fat area, visceral fat area and plasma leptin concentrations, respectively (A) and the significant correlation between PLTP activity and BMI $(r=0.40, p<0.01)$ after correction for kITT value $(\mathbf{B})$

$\left.3.38 \mu \mathrm{mol} \cdot \mathrm{ml}^{-1} \cdot \mathrm{h}^{-1}, n=16\right), \mathrm{T} 2(14.20 \pm 1.38 \mu \mathrm{mol} \cdot$ $\left.\mathrm{ml}^{-1} \cdot \mathrm{h}^{-1}, n=16\right)$, and T3 $\left(15.54 \pm 2.68 \mu \mathrm{mol} \cdot \mathrm{ml}^{-1}\right.$. $\mathrm{h}^{-1}, n=16$ ) (Fig. 3), suggesting that insulin sensitivity does not influence PLTP activity in normolipidaemic, obese, non-diabetic subjects.

When the subjects of the quartiles Q1, Q2 and Q3 were subdivided further into tertiles $\mathrm{T} 1, \mathrm{~T} 2$ and $\mathrm{T} 3$ according to insulin sensitivity expressed as kITT value, PLTP activity was significantly lower in T3 (lowest kITT value) when compared to T2 in the subjects of the second quartile. In the subjects of the third quartile PLTP activity was statistically significantly higher in the third tertile when compared to the first tertile (data not shown). When each quartile was sub- 
Table 3. Clinical characteristics of subjects in the highest quartile of BMI subdivided into tertiles according to the degree of insulin sensitivity

\begin{tabular}{|c|c|c|c|}
\hline & \multicolumn{3}{|c|}{ Tertiles of insulin sensitivity (kITT) } \\
\hline & $\begin{array}{l}\mathrm{T} 1(n=16) \\
\mathrm{kITT}>4 \% / \mathrm{min}\end{array}$ & $\begin{array}{l}\text { T2 }(n=16) \\
\mathrm{kITT} 2.8-4 \% / \mathrm{min}\end{array}$ & $\begin{array}{l}\mathrm{T} 3(n=16) \\
\mathrm{kITT}<2.8 \% / \mathrm{min}\end{array}$ \\
\hline Sex (male/female) & $5 / 11$ & $7 / 9$ & $6 / 10$ \\
\hline $\mathrm{BMI}\left(\mathrm{kg} / \mathrm{m}^{2}\right)$ & $31.6 \pm 2.6$ & $31.4 \pm 3.4$ & $32.4 \pm 3.0$ \\
\hline Waist-to-hip ratio & $0.90 \pm 0.08$ & $0.92 \pm 0.10$ & $0.92 \pm 0.07$ \\
\hline Subcutaneous fat area $\left(\mathrm{cm}^{2}\right)$ & $322 \pm 91$ & $358 \pm 114$ & $324 \pm 116$ \\
\hline
\end{tabular}

Values are means $\pm \mathrm{SD}$

Table 4. Lipoprotein profile and parameters of glucose homeostasis in the highest quartile of BMI subdivided into tertiles according to the degree of insulin sensitivity

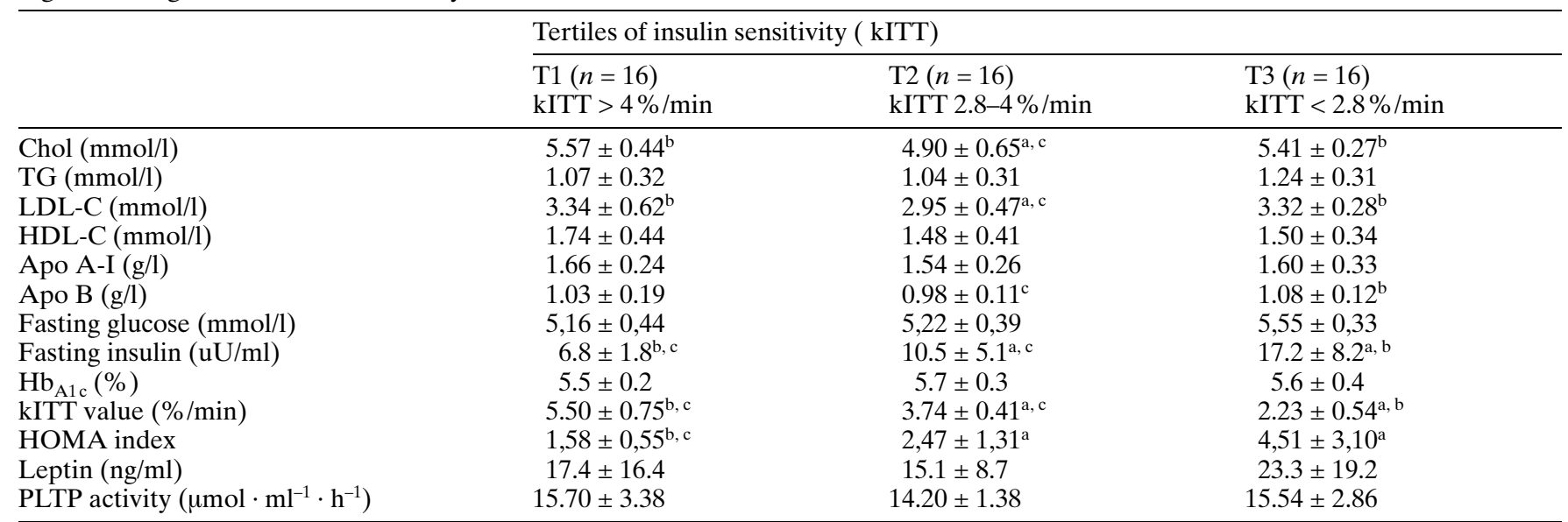

Values are means $\pm \mathrm{SD}$

${ }^{\mathrm{a}} p<0.05$ vs T1; ${ }^{\mathrm{b}} p<0.05$ vs T2; ${ }^{\mathrm{c}} p<0.05$ vs T3

divided further into tertiles $\mathrm{T} 1, \mathrm{~T} 2$ and $\mathrm{T} 3$ according to insulin sensitivity expressed as HOMA index, PLTP activity was similar in each subgroup (data not shown).

\section{Discussion}

Obesity, very common in the Western countries, is frequently associated with insulin resistance and dyslipidaemia. Obesity-associated dyslipidaemia is characterized by hypertriglyceridaemia, excessive postprandial lipemia and, as a consequence, low HDL concentrations and the preponderance of small, dense LDL particles [20, 21, 31, 32]. Each of these features is thought to promote atherogenesis [33, 34]. Pronounced postprandial lipemia could be caused in part by impaired postprandial clearance of TGRL in adipose tissue in obese subjects [35]. Another feature of lipoprotein distribution in obesity is a decreased $\alpha_{1}$-HDL fraction accompanied by elevated pre- $\beta_{1}$-HDL concentrations [36]. Increased pre- $\beta$ -
HDL concentrations were shown to be due to high PLTP activity [11].

We aimed to test whether obesity affects PLTP activity and, thus, HDL metabolism. To exclude a potential confounding effect of insulin resistance, we controlled for this condition and determined PLTP activity in lean and obese patients with and without insulin resistance. Our data show increased PLTP activity in obese patients compared to lean control subjects. This increase appears to be a consequence of obesity itself and not of insulin resistance.

Because our data suggests that PLTP activity is independent of insulin resistance, the question arises which molecular mechanism could be responsible for increased PLTP activity in obesity. The most common alteration in the lipoprotein profile of obese subjects, i.e., hypertriglyceridaemia, appears not to cause increased PLTP activity according to our data: firstly, only normotriglyceridaemic lean and obese subjects were included in our study and secondly, no correlation between lipoprotein concentrations and PLTP activity was observed. 


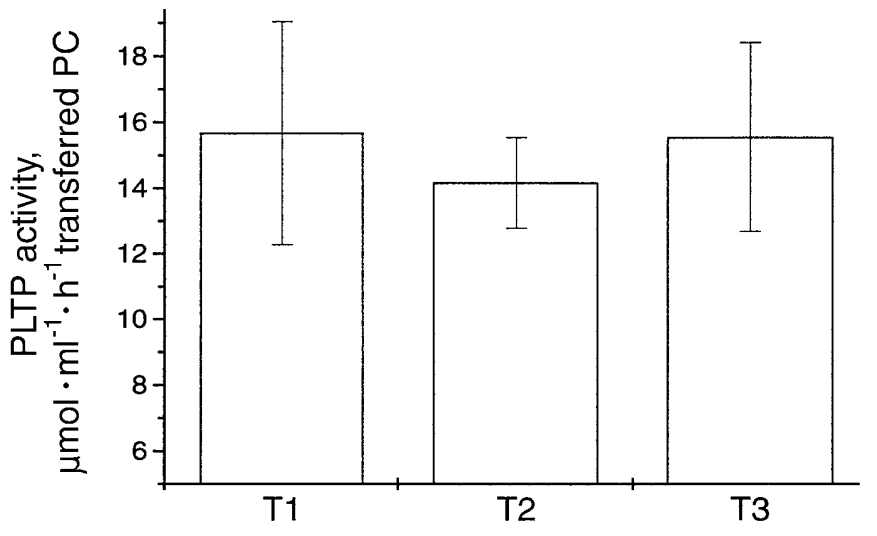

Fig. 3. PLTP activity in obese patients with different degree of insulin sensitivity. Patients of the highest quartile of BMI were subdivided into three groups according to their insulin sensitivity as measured by the short insulin tolerance test (T1: kITT $<2.8 \% / \mathrm{min}, \mathrm{T} 2$ : $\mathrm{kITT} 2.8-4.0 \% / \mathrm{min}, \mathrm{T} 3: \mathrm{kITT}>4.0 \% /$ min). No difference in PLTP activity was found between the three groups. T, tertiles of insulin sensitivity. Means \pm SD

On the basis of our results showing a strong correlation between PLTP activity and body fat mass the most straightforward explanation for the increased PLTP activity in obesity appears to be an increased synthesis of the lipid transfer proteins (CETP and PLTP) by the enlarged mass of adipose tissue. Although we are not able to provide data about PLTP mass, others have shown a tight correlation between PLTP mass and enzymatic activity in normolipidaemic, non-diabetic subjects [37]. Further support of the notion that increased PLTP activity is the result of enlarged adipose tissue mass comes from a work showing a positive correlation between PLTP mRNA content in subcutaneous adipose tissue and BMI [4]. Moreover, our results show a strong correlation between PLTP activity and the adipocyte-derived hormone leptin.

In obesity, two enzymes, PLTP and CETP, released from adipose tissue and a variety of other tissues in a "dose-dependent" manner appear to directly modulate lipoprotein metabolism [3, 4, 38]: enhanced PLTP activity results in a lower HDL-C fraction accompanied by a relative increase in pre- $\beta$-HDL [11]. CETP also catalyses the transfer of cholesteryl ester from HDL to TGRL in exchange for TG and leads to an enrichment of HDL and LDL with TG. Hydrolysis of TG-enriched LDL and HDL results in a proatherogenic lipoprotein pattern characterized by the preponderance of small, dense HDL and LDL particles.

In atherogenesis, the role of increased PLTP activity is less clear. Increased PLTP activity $[12,13]$ is associated with reduced HDL-C concentrations. However, plasma of PLTP-transgenic mice is more efficient than plasma of wild-type mice in preventing the accumulation of intracellular cholesterol in macrophages [11]. Furthermore, increased PLTP activity enhances the formation of pre- $\beta$-HDL particles which have an important function in anti-atherogenic reverse cholesterol transport $[9,10]$. Although these data are contradictory in part, they do emphasize the involvement of PLTP in atherogenesis.

In conclusion, we show that PLTP activity and, as a consequence, lipoprotein metabolism, especially HDL metabolism, is influenced in normolipidaemic, non-diabetic subjects mainly by BMI rather than by insulin resistance. Our data suggest that obesity itself deserves to be accorded the status of an independent determinant of atherosclerosis.

Acknowledgements. The authors wish to thank Dr. V. Weichbold for assistance in statistical analysis and T. Sauper for experimental assistance. This work was supported by grant P11693-Med of the Austrian FWF (to J. R. Patsch) and by grant Nr. 6442 of the Austrian National Bank (Österreichische Nationalbank) (to J.R. Patsch).

\section{References}

1. Albers JJ, Tu A, Wolfbauer G, Cheung MC, Marcovina SM (1996) Molecular biology of phospholipid transfer protein. Curr Opin Lipidol 7: 88-93

2. Albers JJ, Wolfbauer G, Cheung MC et al. (1995) Functional expression of human and mouse plasma phospholipid transfer protein: effect of recombinant and plasma PLTP on HDL subspecies. Biochim Biophys Acta 1258: 27-34

3. Jiang X, Moulin P, Quinet E et al. (1991) Mammalian adipose tissue and muscle are major sources of lipid transfer protein m-RNA. J Biol Chem 266: 4631-4639

4. Dusserre E, Moulin P, Vidal H (2000) Differences in mRNA expression of the proteins secreted by the adipocytes in human subcutaneous and visceral adipose tissues. Biochim Biophys Acta 1500: 88-96

5. Havel RJ, Kane JP, Kashyap ML (1973) Interchange of apolipoproteins between chylomicrons and high density lipoproteins during alimentary lipemia in man. J Clin Invest 52: 32-38

6. Mjos OD, Faergeman O, Hamilton RL, Havel RJ (1975) Characterization of remnants produced during the metabolism of triglyceride-rich lipoproteins of blood plasma and intestinal lymph in the rat. J Clin Invest 56: 603-615

7. Jauhiainen M, Metso J, Pahlman R, Blomquist S, van Tol A, Ehnholm C (1993) Human plasma phospholipid transfer protein causes high density lipoprotein conversion. J Biol Chem 268: 2032-2036

8. Tu A, Nishida HI, Nishida T (1993) High density lipoprotein conversion mediated by human plasma phospholipid transfer protein. J Biol Chem 268: 223098-223105

9. Von Eckardstein A, Jauhiainen M, Huang Y et al. (1996) Phospholipid transfer protein mediated conversion of high density lipoproteins generates preB1-HDL. Biochim Biophys Acta 1301: 255-262

10. Castro GR, Fielding CJ (1988) Early incorporation of cellderived cholesterol into pre-beta-migrating high density lipoprotein. Biochemistry 27: 25-29

11. van Haperen R, van Tol A, Vermeulen P et al. (2000) Human plasma phospholipid transfer protein increases the antiatherogenic potential of high density lipoproteins in transgenic mice. Arterioscler Thromb Vasc Biol 20: 1082-1088 
12. Föger B, Santamarina-Fojo S, Shamburek RD, Parrot CL, Talley GD, Brewer HBJ (1997) Plasma phospholipid transfer protein. Adenovirus-mediated overexpression in mice leads to decreased plasma high density lipoprotein (HDL) and enhanced uptake of phospholipids and cholesteryl esters from HDL. J Biol Chem 272: 27393-27400

13. Ehnholm S, van Dijk KW, van't Hof B et al. (1998) Adenovirus mediated overexpression of human phospholipid transfer protein alters plasma HDL levels in mice. J Lipid Res 39: 1248-1253

14. Jiang XC, Bruce C, Mar J et al. (1999) Targeted mutation of plasma phospholipid transfer protein gene markedly reduces high-density lipoprotein levels. J Clin Invest 103: 907-914

15. Eckel RH, Krauss RM (1998) American Heart Association call to action: obesity as a major risk factor for coronary heart disease. Circulation 97: 2099-2100

16. Rosenbaum M, Leibel RL, Hirsch J (1997) Obesity. N Engl J Med 337: 396-407

17. No authors listed (2000) Owerweight, obesity, and health risk. National Task Force on the Prevention and Treatment of Obesity. Arch Intern Med 160: 898-904

18. Calle EE, Thun MJ, Petrelli JM, Rodriguez C, Heath CWJ (1999) Body mass index and mortality in a prospective cohort of U.S. adults. N Engl J Med 341: 1097-1105

19. Gaenzer H, Neumayr G, Patsch JR (1999) Cardiovascular risk factors and Medicare costs. N Engl J Med 340: 813-814

20. Drexel H, Pfister R, Mitterbauer G, Lechleitner M, Hörtnagl H, Patsch JR (1992) Postprandial lipid and glucose metabolism in women undergoing moderate weight loss by diet plus exercise. Nutr Metab Cardiovasc Dis 2: 1-6

21. Mekki N, Christofilis MA, Charbonnier M et al. (1999) Influence of obesity and body fat distribution on postprandial lipemia and triglyceride-rich lipoproteins in adult women. J Clin Endocrinol Metab 84: 184-191

22. Riemens SC, van Tol A, Sluiter WJ, Dullaart RPF (1998) Plasma phospholipid transfer protein activity is related to insulin resistance: impaired acute lowering by insulin in obese Type II diabetic patients. Diabetologia 41: 929-934

23. Murdoch SJ, Carr MC, Hokanson JE, Brunzell JD, Albers JJ (2000) PLTP activity in premenopausal women: relationship with lipoprotein lipase, HDL, LDL, body fat, and insulin resistance. J Lipid Res 41: 237-244

24. Dullaart RPF, Sluiter WJ, Dikkeschei LD, Hoogenberg K, Von Tol A (1994) Effect of adiposity on plasma lipid transfer protein activities: a possible link between insulin resistance and high density lipoprotein metabolism. Eur J Clin Invest 24: 188-194

25. Riemens SC, van Tol A, Sluiter WJ, Dullaart RPF (1999) Plasma phospholipid transfer protein activity is lowered by $24-\mathrm{h}$ insulin and acipimox administration. Diabetes 48 : $1631-1637$

26. Graci S, Barotta R, Degano C et al. (1999) The intravenous insulin tolerance test is an accurate method for screening a general population for insulin resistence and related abnormalities. J Endocrinol Invest 22: 472-475

27. Matthews DR, Hosker JP, Rudenski AS, Naylor BA, Treacher DF, Turner RC (1985) Homeostasis model assessment: insulin resistance and beta-cell function from fasting plasma glucose and insulin concentrations in man. Diabetologia 28: 412-419

28. Damen J, Regts J, Scherphof G (1982) Transfer of (14C)phosphatidylcholine between liposomes and human plasma high density lipoprotein. Partial purification of a transfer-stimulating plasma factor using a rapid transfer assay. Biochim Biophys Acta 712: 444-452

29. Speijer H, Groener JE, van Ramshorst E, van Tol A (1991) Different locations of cholesteryl ester transfer protein and phospholipid transfer protein activities in plasma. Atherosclerosis 90: 159-168

30. Patsch JR, Patsch W (1986) Zonal ultracentrifugation. Methods Enzymol 129: 3-26

31. Patsch JR, Prasad S, Gotto AM Jr, Patsch W (1987) High density lipoprotein 2. Relationship of the plasma levels of this lipoprotein species to its composition, to the magnitude of postprandial lipemia, and to the activities of lipoprotein lipase and hepatic lipase. J Clin Invest 80: 341-347

32. Miesenbock G, Holzl B, Foger B et al. (1993) Heterozygous lipoprotein lipase deficiency due to a missense mutation as the cause of impaired triglyceride tolerance with multiple lipoprotein abnormalities. J Clin Invest 91: 448-455

33. Patsch JR, Miesenbock G, Hopferwieser Tet al. (1992) Relation of triglyceride metabolism and coronary artery disease. Studies in the postprandial state. Arterioscler Thromb 12: 1336-1345

34. Gardner CD, Fortmann SP, Krauss RM (1996) Association of small low-density lipoprotein particles with the incidence of coronary artery disease in men and women. JAMA 276: 875-881

35. Potts JL, Coppack SW, Fisher RM, Humphreys SM, Gibbons GF, Frayn KN (1995) Impaired postprandial clearance of triacylgylcerol-rich lipoproteins in adipose tissue in obese subjects. Am J Physiol 268: E588-E594

36. Sasahara T, Yamashita T, Sviridov D, Fidge N, Nestel P (1997) Altered properties of high density lipoprotein subfractions in obese subjects. J Lipid Res 38: 600-611

37. Desrumaux C, Athias A, Bessede G et al. (1999) Mass concentration of plasma phospholipid transfer protein in normolipidemic, type IIA hyperlipidemic, type IIB hyperlipidemic, and non-insulin-dependent diabetic subjects as measured by a specific ELISA. Arterioscler Thromb 19: 266-275

38. Radeau T, Robb M, Lau P, Borthwick J, McPherson R (1998) Relationship of adipose tissue cholesteryl ester transfer protein (CETP) mRNA to plasma concentrations of CETP in man. Atherosclerosis 139: 369-376 